\title{
Stress-induced secondary carotenogenesis in Coelastrella rubescens (Scenedesmaceae, Chlorophyta), a producer of value-added keto-carotenoids
}

\author{
Galina Minyuk ${ }^{1}$, Elina Chelebieva ${ }^{1}$, Irina Chubchikova ${ }^{1}$, Natalia Dantsyuk $^{1}$, Irina \\ Drobetskaya ${ }^{1}$, Evgenii Sakhon ${ }^{1}$, Konstantin Chekanov ${ }^{2}$ and Alexei Solovchenko ${ }^{2,3, *}$ \\ ${ }^{1}$ The A.O. Kovalevsky Institute of Marine Biological Research, Sevastopol 299011, Crimea \\ ${ }^{2}$ Biological Faculty of Lomonosov Moscow State University, Moscow 119234, Russia \\ ${ }^{3}$ National Research Nuclear University MEPhi, Centre for Humanities Research and Technology, Moscow 115409, Russia
}

We report on the culture growth and stress-induced secondary carotenogenesis in a biotechnologically promising but largely unexplored chlorophyte Coelastrella rubescens strain Vinatzer/InnsbruckV 195. Changes in the cell morphometry, biomass accumulation, its carotenoid and fatty acid profiles were followed in the cultures supplemented with either inorganic $\left(\mathrm{CO}_{2}\right)$ or organic (sodium acetate) carbon on the background of low-pH stress. Collectively, the results of the study characterize C. rubescens as a biotechnologically promising, potentially double-purpose organism. It produces several secondary keto-carotenoids with a considerable proportion of astaxanthin and canthaxanthin. At the same time, the cell lipid fatty acid profile of this microalga is suitable for obtaining a high-quality biodiesel complying with the strictest EN14214 European standard.

Key Words: biodiesel; Coelastrella (Scotiellopsis) rubescens; $\mathrm{CO}_{2}$; cultivation; fatty acids; growth rate; $\mathrm{PH}$; pigments

Abbreviations: ALA, $\alpha$-linolenic acid; Ast, astaxanthin; Car, carotenoids; Chl, chlorophyll(s); FA, fatty acids; HPLC, highperformance liquid chromatography; ITS, internal transcribed spacer; OA, oleic acid; PAR, photosynthetically active radiation; PCR, polymerase chain reaction; ROS, reactive oxygen species

\section{INTRODUCTION}

Recent decades were marked by explosive growth of interest to carotenogenic microalgae as an important source of value-added natural carotenoids (Car)-a much sought-after nutraceuticals, cosmetics and medicine components with a plethora of beneficial effects on health (Lorenz and Cysewski 2000, Leu and Boussiba 2014, Solovchenko and Chekanov 2014). Despite rapid expansion of knowledge of the biology of and growing number of reports on these microalgae as novel sources of Car (Boussiba 2000, Lorenz and Cysewski 2000, Leu and Boussiba 2014), the number of industrially grown carotenogenic microalgae remains essentially unchanged for a long time including the chlorophytes Haematococcus pluvialis (Han et al. 2013) and Dunaliella salina (Borowitzka 2013). A common reason for this is a lack of in-depth knowledge and hence the absence of a universal screening strategy for new carotenogenic microalgae, a group constituted by the organisms vastly different in terms of
(9) $\$$ This is an Open Access article distributed under the terms of the Creative Commons Attribution Non-Commercial License (http://creativecommons.org/licenses/by-nc/3.0/) which permits unrestricted non-commercial use, distribution, and reproduction in any medium, provided the original work is properly cited.
Received February 1, 2017, Accepted August 6, 2017

*Corresponding Author

E-mail: solovchenko@mail.bio.msu.ru

Tel: +007-495-939-25-87, Fax: +007-495-939-38-07 
their taxonomy, biology, and ecology. This diversity complicates screening for promising producer strains suitable for development of economically viable technologies of Car-enriched biomass generation. Another reason is the tough competition of the natural Car from microalgae with their synthetic counterparts which almost drove out of market natural Car-based feed additives (Lorenz and Cysewski 2000).

Organisms capable of producing a broader line of marketable bioproducts such as value-added keto-carotenoids (e.g., astaxanthin and cantaxanthin) and neutral lipids convertible to biofuel might have an advantage allowing to develop more diversified biotechnologies using the biorefinery approach (Lam and Lee 2011, Borowitzka and Moheimani 2013, Subramanian et al. 2013). In this context, a chlorophyte Coelastrella (Scotiellopsis) rubescens Kaufnerová et Eliáš 2013 (Sphaeropleales, Scenedesmaceae) can be considered as a promising organism with several traits beneficial from the standpoint of mass cultivation. Coelastrella rubescens combines the capability of co-accumulation of secondary Car (up to $2 \% \mathrm{DW}$ ) and lipids (up to $50 \% \mathrm{DW}$ ) with high tolerance to diverse stresses (Chubchikova et al. 2009, Minyuk et al. 2010, 2016). Still, the literature available to us contains scarce reports on suitability of $C$. rubescens for biotechnological production of value-added Car and / or lipid precursors of biodiesel. Recently, we characterized the growth and nutrient uptake kinetics of green (vegetative) cells of $C$. rubescens IPPAS H-350 under pH-stat conditions maintained by controlled direct injection of $\mathrm{CO}_{2}$ into the culture (Minyuk et al. 2016), but the stress-induced carotenogenesis, the process essential for industrial scale production of the valuable Car pigments, remained so far unelucidated in this organism.

This work aimed at characterization of secondary carotenogenesis and fatty acid (FA) profile $C$. rubescens under two-stage batch cultivation condition. Instead of focusing on individual stress effect, we applied a combination stressor including raising the irradiance and deprivation of nutrients by dilution of the culture. We followed the changes in cell morphometry and culture productivity. In addition, we tested a novel approach to enhancement of the secondary ketocarotenoid biosynthesis by acidification of the medium to $\mathrm{pH} 5$ by direct $\mathrm{CO}_{2}$ injection and / or addition of organic carbon source sodium acetate, NaAc (to the final level of $25 \mathrm{mmol}$ ).

\section{MATERIALS AND METHODS}

\section{Strain and its molecular identification}

A strain of Coelastrella (Vinatzer) Scotiellopsis rubescens Kaufnerová et Eliáš (Scenedesmaceae, Sphaeropleales, Chlorophyceae) obtained from the collection of microalgae of the Timiryazev Institute of Plant Physiology, Russian Academy of Sciences in 2006 as Scotiellopsis rubescens Vinatzer strain IPPAS H-350 (Vinatzer/Innsbruck V 195 = CCALA 475) (Kaufnerová and Eliáš 2013).

For the genomic DNA isolation, microalgal biomass sample (2-5 mg DW) was collected and subjected to three cycles of liquid nitrogen freezing-thawing to destroy the though cell walls. DNA was extracted using MagJET Plant Genomic DNA Kit (Thermo Scientific, Billerica, MA, USA) according to the manufacturer's protocol. Quality of the DNA was evaluated by electrophoresis in $1.5 \%$ agarose gel stained with ethidium bromide $\left(0.2 \mu \mathrm{g} \mathrm{mL} \mathrm{mL}^{-1}\right)$.

The DNA sequences encoding 18S rRNA from nuclear ribosomal gene cluster (18SrRNA) was amplified by polymerase chain reaction (PCR) as described in Buchheim et al. (2013) using following primers: internal transcribed spacer (ITS) 2, gctgcgttcttcatcgatgc; NS1, gtagtcatatgcttgtctc. PCR product was purified with Cleanup Standard (Evrogen, Moscow, Russia) reagents according to manufactures protocol and sequenced with using BigDye Terminator v. 3.1 (Applied Biosystems, Foster City, CA, USA) reagents on 3730 DNA Analyzer (Applied Biosystems) automated sequencer.

During the analysis of the obtained DNA sequences homologous sequences were searched against NCBI GeneBank (nucleotide collection $\mathrm{nr} / \mathrm{nt}$ database) using BLAST (http://blast.ncbi.nlm.nih.gov/) software (Altschul et al. 1990). The sequences were further analyzed with MEGA 6.06 software (Tamura et al. 2013). Multiple alignment was performed using 10 iterations of the MUSCLE algorithm (Edgar 2004) with other parameters set to default values.

Phylogenetic trees were constructed with using maximum likelihood and neighbor-joining algorithms (Saitou and Nei 1987) with K2 model of evolutionary distance calculation and other parameters set to default values in MEGA 6.06. The accuracy of the tree topology was tested using bootstrap analysis (Felsenstein 1985) with 1,000 replicates. 


\section{Cultivation conditions}

The stock culture was maintained in the solidified (1.5\% agar) BBM medium (Bishoff and Bold 1963) at 15$16^{\circ} \mathrm{C}$ and $25 \mu \mathrm{mol}$ quanta $\mathrm{m}^{-2} \mathrm{~s}^{-1}$. In subsequent experiments, we employed two-stage cultivation as a proven approach for study of carotenogenic microalgae (Boussiba 2000, Fábregas et al. 2001, Chubchikova et al. 2010).

At the first ("green") stage the microalga was batchcultivated for 11 days in 1 L Erlenmeyer flasks in the modified BBM medium containing $\mathrm{NaNO}_{3} 1,310 \mathrm{mg} \mathrm{L}^{-1}$, $\mathrm{MgSO}_{4} \cdot 7 \mathrm{H}_{2} \mathrm{O} 75 \mathrm{mg} \mathrm{L}-1, \mathrm{NaCl} 25 \mathrm{mg} \mathrm{L}^{-1}, \mathrm{~K}_{2} \mathrm{HPO}_{4} \cdot 3 \mathrm{H}_{2} \mathrm{O}$ $42 \mathrm{mg} \mathrm{L}^{-1}, \mathrm{KH}_{2} \mathrm{PO}_{4} 99 \mathrm{mg} \mathrm{L}^{-1}$, EDTA-Na $50 \mathrm{mg} \mathrm{L}^{-1}, \mathrm{KOH}$ $31 \mathrm{mg} \mathrm{L}-1, \mathrm{H}_{3} \mathrm{BO}_{3} 11 \mathrm{mg} \mathrm{L}^{-1}, \mathrm{ZnSO}_{4} \cdot 7 \mathrm{H}_{2} \mathrm{O} 8.82 \mathrm{mg} \mathrm{L}^{-1}$, $\mathrm{MnCl}_{2} \cdot 4 \mathrm{H}_{2} \mathrm{O} 1.44 \mathrm{mg} \mathrm{L}{ }^{-1}, \mathrm{Na}_{2} \mathrm{MoO}_{4} \cdot 2 \mathrm{H}_{2} \mathrm{O} 2.42 \mathrm{mg} \mathrm{L}^{-1}$, $\mathrm{CuSO}_{4} \cdot 5 \mathrm{H}_{2} \mathrm{O} 1.57 \mathrm{mg} \mathrm{L}^{-1}, \mathrm{Co}\left(\mathrm{NO}_{3}\right)_{2} \cdot 6 \mathrm{H}_{2} \mathrm{O} 0.49 \mathrm{mg} \mathrm{L}^{-1}$, $\mathrm{FeSO}_{4} \cdot 7 \mathrm{H}_{2} \mathrm{O} 4.98 \mathrm{mg} \mathrm{L}^{-1}, \mathrm{CaCl}_{2} 18.9 \mathrm{mg} \mathrm{L}^{-1}+1 \mu \mathrm{L}$ of concentrated $\mathrm{H}_{2} \mathrm{SO}_{4}$ at $25 \pm 1^{\circ} \mathrm{C}$ and a unilateral side illumination with daylight fluorescent lamps "Feron" DL 20W 6400K (Russia), $140 \mu \mathrm{mol}$ PAR quanta $\mathrm{m}^{-2} \mathrm{~s}^{-1}$ (as measured at the flask surface), $15 \mathrm{~h}$ light : $9 \mathrm{~h}$ dark. The culture was continuously sparged with air at a rate of $1 \mathrm{vvm}$ using a compressor Resun ACO-9630 (Resun, China). During the light period, the $\mathrm{pH}$ was maintained at a constant level $(7.0 \pm 0.05)$ by means of direct supply of $\mathrm{CO}_{2}$ from a gas cylinder controlled by solenoid valves Camozzi A7E (Camozzi, Brescia, Italy) and a digital pH controller Aqua Medic pH 2001C (Aqua Medic GmbH, Bissendorf, Germany). A culture started at a pH 7.0 and sparged with atmospheric air only served as the control. The initial cell density and volume of the cultures were $1.0 \times 10^{6} \pm 0.16 \times$ $10^{5}$ cells $\mathrm{mL}^{-1}$ and $0.45 \mathrm{~L}$, respectively.

To induce carotenogenesis (the second, "red" stage of cultivation), the cells were pelleted by centrifugation (770 g, $2 \mathrm{~min}$ ) on an Eppendorf 5810 centrifuge (Eppendorf, Hamburg, Germany) and re-suspended in $0.45 \mathrm{~L}$ of the modified BBM medium with 10 -fold reduced $\mathrm{N}$ and $\mathrm{P}$ content (4.12 $\mathrm{mg} \mathrm{L}^{-1} \mathrm{NO}_{3}-\mathrm{N} ; 5.32 \mathrm{mg} \mathrm{L}^{-1} \mathrm{PO}_{4}-\mathrm{P}$ ). The starting cell density was, as a result, $2 \times 10^{6}$ cells $\mathrm{mL}^{-1}$, i.e., 11 fold lower in comparison with the cell density attained by the end of the "green" stage. At the "red" stage, the cultures were illuminated from both sides (the total PAR irradiance of $240 \mu \mathrm{mol}$ PAR quanta $\mathrm{m}^{-2} \mathrm{~s}^{-1}$ ). Considering the reduced cell density at the "red" stage, the effective irradiance at this stage is estimated to be 20 -fold higher than that employed at the "green" stage constituting the stress necessary for the induction of secondary carotenogenesis.

To provide an additional stress inducing the biosynthesis of the secondary Car, we lowered the $\mathrm{pH}$ of the culture to 5.0 (Zhang et al. 1997) adjusting the $\mathrm{CO}_{2}$ inflow (this variant was designated as ' $\mathrm{CO}_{2}$ ') or supplemented the culture with sodium acetate, $\mathrm{CH}_{3} \mathrm{COONa} \cdot 3 \mathrm{H}_{2} \mathrm{O}$ (Kobayashi et al. 1993), the latter treatment was designated as 'NaAc.' Sodium acetate was supplemented at 2, 4, and 6th day of cultivation as $2 \mathrm{M}$ solution to a final concentration of 25 $\mathrm{mmol} \mathrm{L} \mathrm{L}^{-1}$. A culture receiving no additional carbon source served as the control in these experiments.

\section{Monitoring of the culture growth and cell size}

The number (n) and volume (V) of the cells were analyzed using a flow cytometer (Hyka et al. 2013) FC 500 CytomicsTM $\lambda 488$ (Beckman Coulter, Brea, CA, USA). Cell $n$ was evaluated on the log-scaled two-parameter cytograms of forward scattering. Linear cell size was measured on micrographs captured with a photomicroscope Leica DM-1000 (Leica Biosystems, Nussloch, Germany) using ImageJ software (NIH, Bethesda, MD, USA). Cell volumes were calculated using equation for elongated spheroid volume basing on 100 sampled cells.

Dry weight was determined gravimetrically on nitrocellulose membrane filters Sartorius SM 11301 N (Sartorius, Goettingen, Germany) with a pore size of $3 \mu \mathrm{m}$ (Vonshak 1985).

Average yield $\left(\mathrm{P}_{\mathrm{AVG}}\right)$ and specific growth rate $\left(\mu_{\mathrm{AVG}}\right)$ were calculated for the period of 0-10 days on the cell number and DW basis (Wood et al. 2005) as

$$
\begin{aligned}
& \mathrm{P}_{\mathrm{AVG}}=\left(\mathrm{N}_{1}-\mathrm{N}_{0}\right) /\left(\mathrm{t}_{1}-\mathrm{t}_{0}\right) ; \mathrm{P}_{1}=\left(\mathrm{DW}_{1}-\mathrm{DW}_{0}\right) /\left(\mathrm{t}_{1}-\mathrm{t}_{0}\right) ; \\
& \mu_{\mathrm{AVG}}=\ln \left(\mathrm{N}_{1} / \mathrm{N}_{0}\right) /\left(\mathrm{t}_{1}-\mathrm{t}_{0}\right) ; \mu_{1}=\ln \left(\mathrm{DW}_{1} / \mathrm{DW}_{0}\right) /\left(\mathrm{t}_{1}-\mathrm{t}_{0}\right)
\end{aligned}
$$

, where $\mathrm{P}_{\mathrm{AVG}}$ is the average productivity on cell number basis, cell $\mathrm{mL}^{-1} \mathrm{~d}^{-1} ; \mathrm{N}_{0}$, the initial cell density, cell $\mathrm{mL}^{-1} ; \mathrm{N}_{1}$, cell density after $10 \mathrm{~d}$ of cultivation, cell $\mathrm{mL}^{-1} ;\left(\mathrm{t}_{1}-\mathrm{t}_{0}\right)$, the duration of cultivation, $\mathrm{d}$; $\mathrm{P}_{1}$, the average productivity on DW basis, $\mathrm{mg} \mathrm{L}^{-1} \mathrm{~d}^{-1} ; \mathrm{DW}_{0}$, initial $\mathrm{DW}, \mathrm{mg} \mathrm{L}^{-1}$; $\mathrm{DW}_{1}$, the final $\mathrm{DW}, \mathrm{mg} \mathrm{L}^{-1} ; \mu_{\mathrm{AVG}}$, mean specific growth rate on cell number basis, $d^{-1} ; \mu_{1}$, mean specific growth rate on DW basis, $\mathrm{d}^{-1}$.

Doubling time was calculated as $T_{d}=\ln (2)\left(\mu^{-1}\right)$, where $\mu$ is a mean specific growth rate on cell number basis (Wood et al. 2005).

\section{Pigment assay}

Pigments were extracted with dimethyl sulfoxide (Pal et al. 2011) or acetone (high-performance liquid chromatography [HPLC] grade; Merck, Darmstadt, Germany) using the same extraction procedure. Content of chlorophyll (Chl) $a$ and $b$ and total Car in the extracts was determined with a spectrophotometer Agilent Cary 300 (Agilent, San- 
ta Clara, CA, USA) (Lichtenthaler 1987, Solovchenko et al. 2010). The Car profile was resolved by HPLC as described previously (Chekanov et al. 2014).

\section{Cell composition analysis}

Lipids were extracted using the method of Bligh and Dyer (1959). Total cell lipid content was determined by a colorimetric sulfo-phospho-vanilin method (Ahlgren and Merino 1991) via a calibration curve constructed with food grade olive oil (ABEA, Chania, Greece) purified on a $\mathrm{Al}_{2} \mathrm{O}_{3}$ column. Average culture lipid productivity at the "red" stage was calculated as $\mathrm{P}_{\mathrm{L}}=\left(\mathrm{L}_{1}-\mathrm{L}_{0}\right) /\left(\mathrm{t}_{1}-\mathrm{t}_{0}\right)$, where $\mathrm{L}_{1}$ and $\mathrm{L}_{0}$ are total lipid contents at the beginning $\left(\mathrm{t}_{0}\right)$ and at the end $\left(\mathrm{t}_{1}\right)$ of the "red" stage.

FA composition of the cell lipids was determined by gas chromatography mass spectrometry of the FA methyl esters obtained by direct transesterification of cells (Chekanov et al. 2014). The FA profile data were used for prediction of the properties of the biodiesel (Islam et al. 2013) potentially obtained from the $C$. rubescens biomass with the corresponding FA profile.

Total protein was assayed using the Lowry method (Lowry et al. 1951), carbohydrates were assayed using a phenol-sulfur reagent (DuBois et al. 1956).

\section{Assay of nutrients in the medium}

The concentration of $\mathrm{NO}_{3}^{-}$in the medium was monitored using a nitrate-selective electrode 9307BNWP (Thermo Orion, Beverly, MA, USA), concentration of $\mathrm{PO}_{4}{ }^{3-}$ - by the Murphy-Riley colorimetric method (Murphy and Riley 1962).

All experiments were carried out in three biological replications with three analytical replications for each. Mean values and their standard deviations are shown in the figures, unless stated otherwise. The significance of the difference between the averages was tested using Student's t-test $(\mathrm{p}<0.05)$.

\section{RESULTS AND DISCUSSION}

\section{Confirmation of the taxonomy status of the studied strain}

In the beginning of the work it was essential to confirm the taxonomical status of the studied microalgal strain using a molecular identification-based approach due to recent revisions in this taxonomy domain (Punčochářová and Kalina 1981, Kaufnerová and Eliáš 2013). Towards this end, the fragment of genomic DNA encoding 18S rRNA (predicted length 2,200 bp) was isolated and sequenced (GenBank ID KT962984). The homology search using BLAST showed the maximal (95-99\%) identity of the obtained sequence with 18SrRNA gene of microalgae from the family Scenesesmaceae as can be seen from the phylogenetic tree (Fig. 1). The strain IPPAS H-350 clustered with microalgae from family Scenedesmaceae (such as Coelastrum, Scenedesmus, Acutodesmus) forming a sub-group with microalgae $S$. terrestris CCAP-279-1, C. striolata CAUP H 3602, Coelastrella sp. KGU-HN001. The BLAST search revealed the highest similarity of the $18 \mathrm{Sr}$ $R N A$ sequences among the genera Scotiellopsis Vinatzer and Coelastrella Chodat so the used locus did not provide enough selectivity to discern reliably the genera Scotiellopsis and Coelastrella based solely on 18SrRNA sequence data.

At the same time, Scotiellopsis clearly differs from Coelastrella by the presence of polar thickenings (Punčochářová and Kalina 1981, Kaufnerová and Eliáš 2013) although Hanagata (1998) proposed joining these two genera with the genus Scenedesmus on the grounds of high similarity of their $18 S r R N A$ sequence. Subsequent analysis of compensatory base changes in the ITS II of the nuclear ribosomal gene cluster and 18SrRNA carried out by Kaufnerová and Eliáš (2013) revealed the paraphyletic nature of the genus Scotiellopsis. As a result, the type species $S$. rubescens was transferred to genus Coelastrella with name $C$. rubescens. Accordingly, the currently most correct name of the studied strain IPPAS H-350 is likely C. rubescens and Scotiellopsis rubescens and Scenedesmus rubescens are its basyonims. At the same time, the systematic of the chlorophytes within the order Sphaeropleales is still far from established and further changes might be expected.

\section{Specifics of the two-stage cultivation of Coelas- trella rubescens}

Changes in the cell morphology and physiology at the "green" stage. The two-stage batch culture is a proven approach for screening and characterization of carotenogenic microalgae. This method provides a large body of diverse valuable information about the algal growth and metabolism from a single experiment. In this approach, the Car productivity of the culture is constituted by the two key component: cell division rate under optimal conditions at the "green" stage and survival of the cells and Car biosynthesis rate under the stress at the "red" stage. 


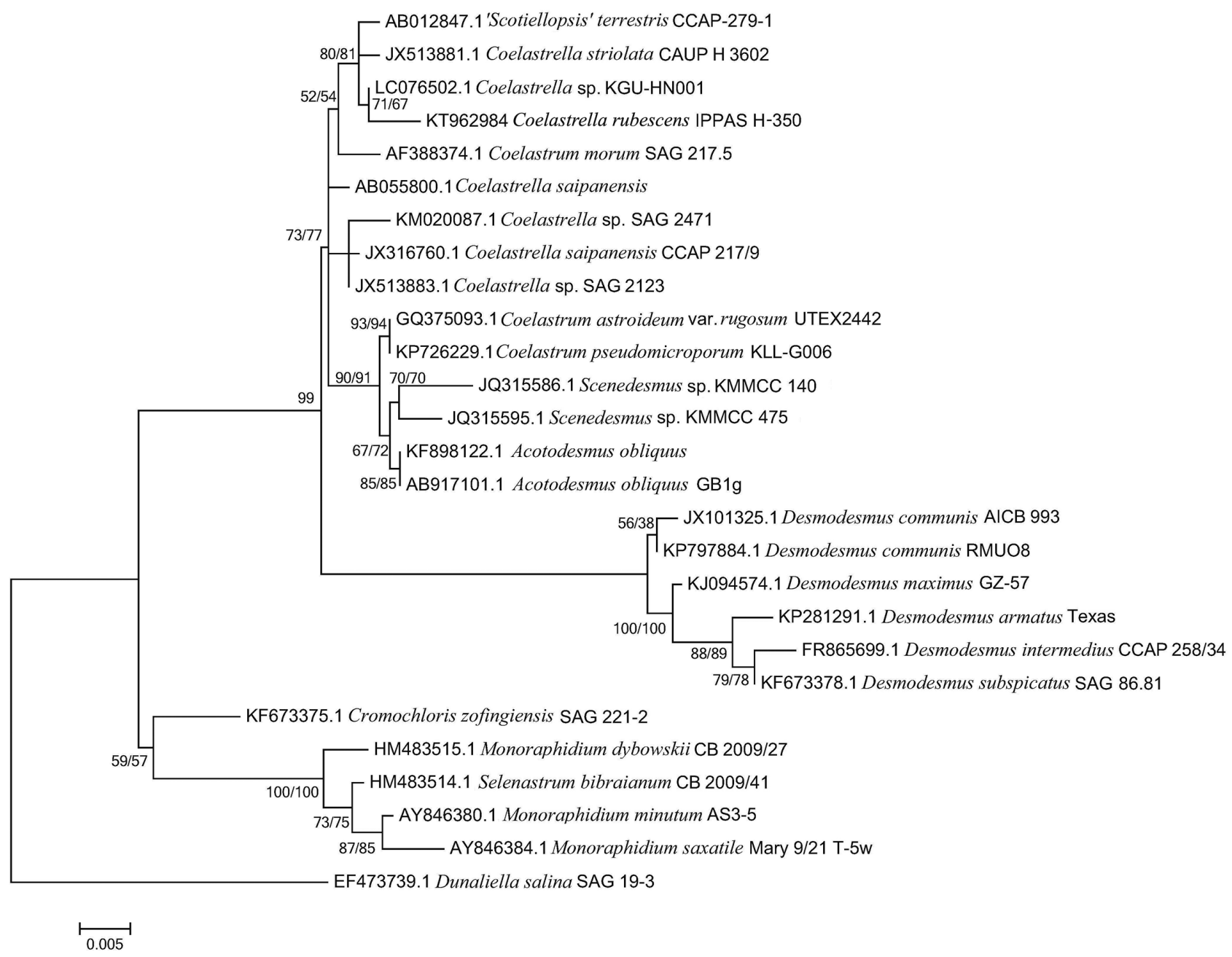

Fig. 1. Phylogenetic tree for selected microalgae from the order Sphaeropleales constructed by maximum likelihood (ML) and neighbor joining (NJ) algorithm based on $\mathrm{K} 2$ model of nucleotide substitution $(+G$, parameter $=0.70 ;[+l], 60 \%$ sites). The tree with the highest log likelihood $(-2,631.5234)$ is shown. The tree is drawn to scale, with branch lengths measured in the number of substitutions per site. ML / NJ bootstrap values $>50$ are shown near the branches.

Notably, a severe combination stress (e.g., elevated irradiance and essential nutrient deprivation) is often applied at the "red" stage (Boussiba 2000, Fábregas et al. 2001, Minyuk et al. 2010). In this work, we achieved these conditions by diluting the "green"-stage pre-cultures.

As was earlier shown for Haematococcus pluvialis (Wang et al. 2014), physiological condition and growth phase during the stress-induction of secondary carotenogenesis are crucial for the cell survival and hence for the productivity at the "red" stage. In physiologically homogenous "green" cultures dominated by monad cells devoid of secondary Car, the stress could lead to a mortality rate as high as $40-60 \%$. In more heterogeneous cultures including, apart from the monad cells, a sizeable proportion of immotile palmelloid cells which possess
Car / Chl mass ratio above 0.35 and hence feature a higher stress tolerance, the mortality dropped drastically to $4 \%$ (Minyuk 2008). In this work, we tested if the same pattern applies to C. rubescens. We subjected pre-stationary cultures of this microalga to the stress with simultaneous recording of their functional condition (growth rate, cell morphology and nutrient uptake).

Combination of cell suspension dilution, nutrient limitation and increase of the incident irradiance (for more detail, see Materials and Methods) reliably induced secondary carotenogenesis in the carotenogenic microalgae (Minyuk et al. 2010, 2016, Chelebieva et al. 2013, Han et al. 2013). Here, we tried to boost carotenogenesis by supplying extra carbon sources. This treatment is expected, on one hand, to increase the carbon flow into the Car bio- 

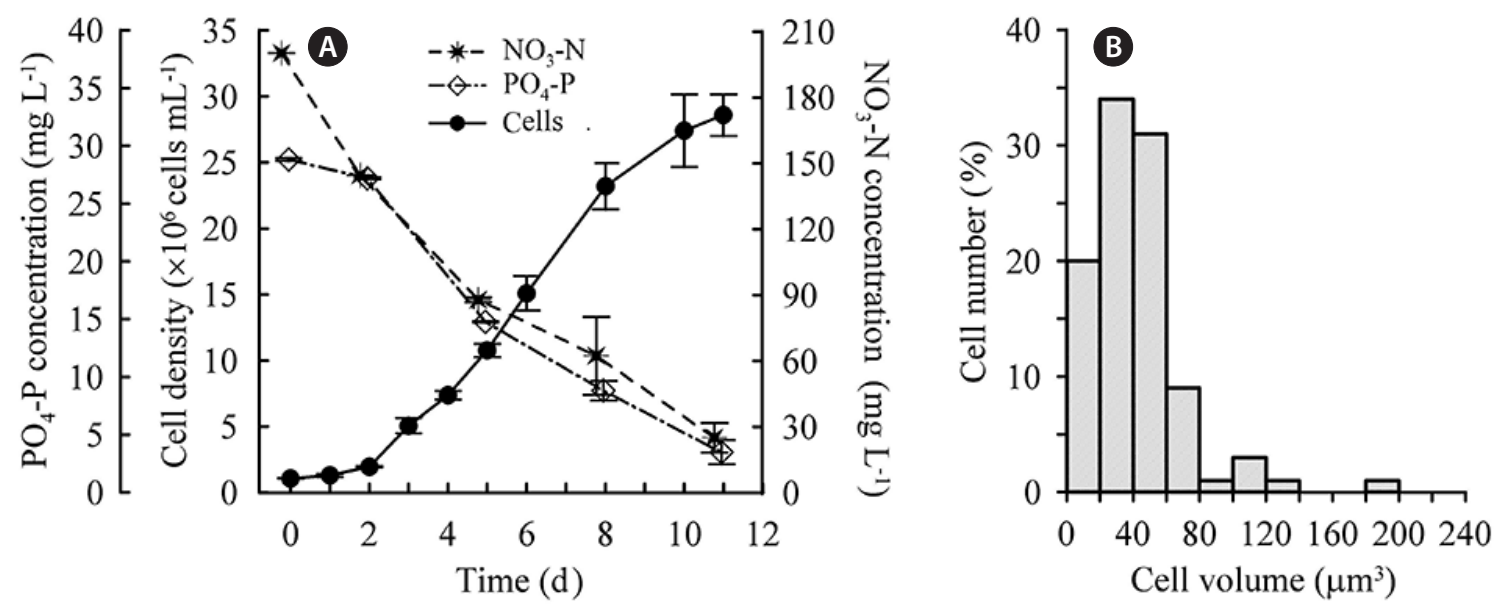

Fig. 2. Changes in the cell number and biogenic element contents in the Coelastrella rubescens culture at the "green" cultivation stage (A) and size distribution of the cell population at the 11 th day of cultivation (B).

synthesis pathway and, on the other hand, to exacerbate the stress contributing to the excess of fixed carbon on the background of limited sink capacity of the cell metabolism at the "red" stage (Lemoine and Schoefs 2010, Recht et al. 2014, Solovchenko 2015). To increase the stress intensity, the carbon oversupplementation in form of NaAc addition (Kobayashi et al. 1993) or $\mathrm{CO}_{2}$ addition was combined with acidification of the culture medium to a level considerably below the optimum for green algae via $\mathrm{CO}_{2}$ injection (Zhang et al. 1997). Thus, the exposure to elevated $\mathrm{CO}_{2}$ levels enhanced accumulation of astaxanthin in Chlorococcum sp. (Zang et al. 1997), Chlorella zofingiensis (Kessler and Czygan 1965) and Chlorococcum wimmeri (Brown et al. 1967), likely due to disturbance of the cell pH homeostasis (Solovchenko and Khozin-Goldberg 2013, Liu et al. 2016). In another experimental treatment, additional source of organic carbon was used (NaAc). In the lower concentration range $(<10 \mathrm{mmol}) \mathrm{NaAc}$ is readily consumed by chlorophyte species capable of mixotrophic growth (Haematococcus pluvialis, Micractinium pusillum, Chlamydomonas reinhardtii, Chlorella sp., etc.). Although supplementation of cultures with NaAc facilitates the growth under insufficient light energy conditions, higher concentration of NaAc impair growth in dose-dependent manner (Heifetz et al. 2000, Bouarab et al. 2004, Minyuk 2008, Ji et al. 2013). In astaxanthin-producing species NaAc concentrations in the range 45-100 mmol exacerbate the low-nutrient and high-light stresses considerably promoting thereby the accumulation of the secondary carotenoids (Kobayashi et al. 1993, Sarada et al. 2002, Minyuk 2008, Yu et al. 2015), likely via an increase in reactive oxygen species (ROS) formation mediated by inhibition of catalase, a key antioxidant enzyme (Beers and Sizer 1956, Özben 2013).

As was shown earlier, supplementation of the culture with $50 \mathrm{mmol} \mathrm{NaAc}$ during the transition from the "green" to the "red" stage enhances the secondary Car content in the cells more than two-fold. However, there was no measurable increase in the Car productivity due to a considerable increased in the cell mortality (Chubchikova et al. 2010). Therefore, to avoid the excessive the cell mortality, we supplemented NaAc thrice with 2-d intervals, half of concentration normally used in previous our experiments with C. rubescens $(0.25 \mathrm{mmol})$.

Changes in the cell morphology and physiology at the "green" stage. The kinetics of growth of and nutrient uptake by the batch culture of $C$. rubescens in the "green" stage are shown in Fig. 2A, see also Supplementary Fig. S1. Under our experimental conditions, the maximum and average specific growth rates were $0.95 \pm 0.09$ and $0.32 \pm$ $0.002 \mathrm{~d}^{-1}$, respectively; the average doubling time $-2.33 \pm$ $0.03 \mathrm{~d}^{-1}$, and the average DW-based productivity-112.68 $\pm 6.72 \mathrm{mg} \mathrm{L}^{-1} \mathrm{~d}^{-1}$. By the end of the "green" stage, the growth rate of the culture slowed down. The culture represented a homogenous suspension of individual cells lacking the cell aggregates typically formed by this species under adverse conditions (Chubchikova et al. 2010).

The cells took up $\mathrm{NO}_{3}{ }^{-}$and $\mathrm{PO}_{4}{ }^{3-}$ from the medium in a molar ratio of 15.4 at an average rate $64.86 \pm 6.77$ and $9.35 \pm 0.71 \mathrm{pg}$ per 10,000 newly formed cells, respectively. The residual nutrient content in the medium was, by the end of the "green" stage, $25.03 \pm 3.92 \mathrm{mg} \mathrm{L}^{-1} \mathrm{NO}_{3}{ }^{-}$and 2.96 $\pm 0.97 \mathrm{mg} \mathrm{L}^{-1} \mathrm{PO}_{4}{ }^{3-}(12.5 \%$ and $10.5 \%$ of the initial con- 

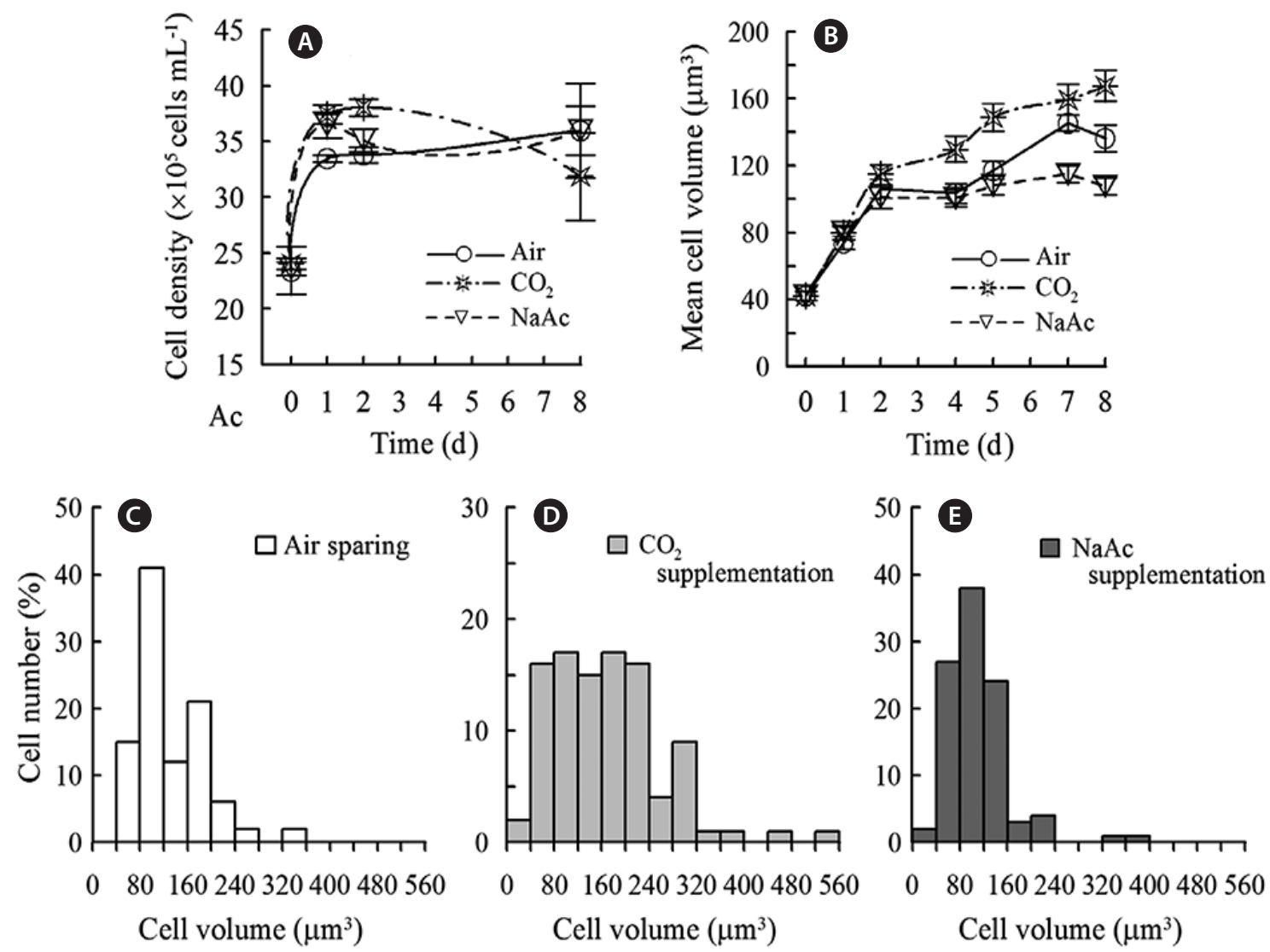

Fig. 3. The changes in number (A) and average size (B) of the Coelastrella rubescens cells at the "red" stage and cell size distribution (C-E) in the culture at the eighth day with air sparging (curve 1) (C), $\mathrm{CO}_{2}$ injection (curve 2) (D), or NaAc supplementation (curve 3) (E).

tent, respectively). The cell size distribution of the culture was governed by young cells ( $\mathrm{V} \leq 60 \mu \mathrm{m}^{3} ; 85 \%$ of total cell number including $20 \%$ of the small, newly released autospores, $\left.\mathrm{V}=10-20 \mu \mathrm{m}^{3}\right)$. The older cells $\left(\mathrm{V}>120 \mu \mathrm{m}^{3}\right)$ were below $2 \%$ (Fig. $2 \mathrm{~B}$ ).

\section{Culture growth and cell morphology as a func- tion of cultivation conditions at the "red" stage}

A characteristic response of $C$. rubescens to abrupt stress triggering the accumulation of secondary Car brought about a short transient increase of cell division rate regardless of the nature of the stress (Fig. 3A). After one day of stress, the cell number increased by $43 \%$ in the air-sparged control and by $55-56 \%$ in the cultures supplemented with $\mathrm{CO}_{2}$. A similar response to the same stress was observed in Ettlia carotinosa Komárek 1989 (Volvocales), although the cell division in E. carotinosa did not stop almost to the end of the "red" stage resulting in a considerable (7.4-fold) decline in the cell volume (Che- lebieva et al. 2013). In the present work, the cell division stopped already at the second day, so the cell density of the carbon-supplemented cultures declined considerably to the end of the "red" stage. Remarkably, the mild NaAc stress did not increase the cell survival in this experimental variant. On the contrary, the cell mortality was the highest in this case and like that normally occurring after a single addition of $\mathrm{NaAc}$ to the concentration of $50 \mathrm{mmol}$ (Chubchikova et al. 2009). It is likely that in the young Coelastrella cells exposure to $25 \mathrm{mmol} \mathrm{NaAc}$ at the second day of cultivation resulted in an increase in the ROS level (Kobayashi et al. 1993, Yu et al. 2015) hence the cessation of cell division; repeated addition of NaAc lead to a decline in the culture density. A similar effect might take place in the $\mathrm{CO}_{2}$ over-supplemented cultures. Thus, in Thalassiosira weissflogii cells an abrupt decline in $\mathrm{pH}$ triggered a dramatic increase in malonic dialdehyde, the product of lipid peroxidation and a marker of oxidative stress (Liu et al. 2016). Still we did not observe the mass death of young cells such as took place in $H$. pluvialis cul- 

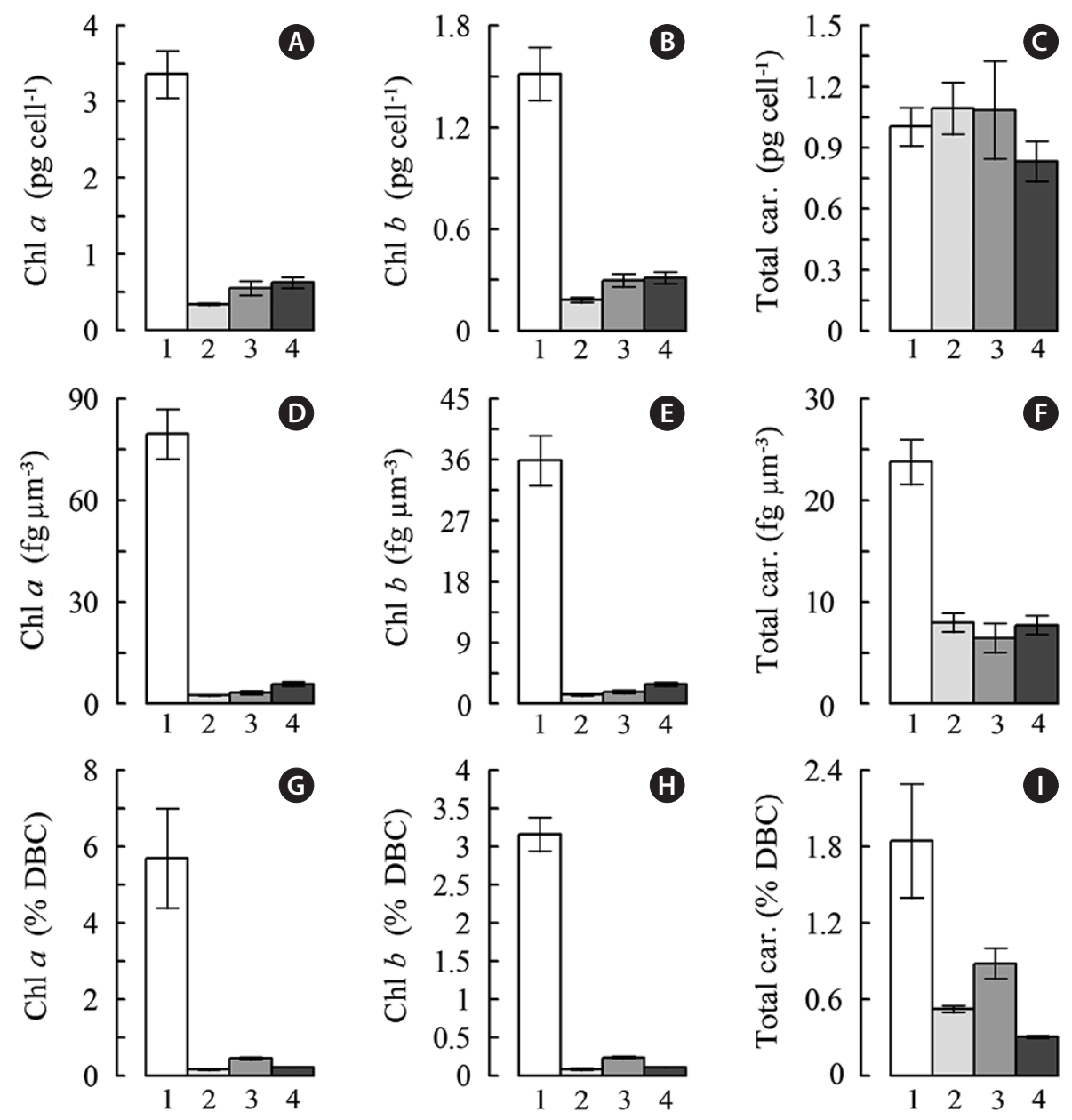

Fig. 4. Pigment content expressed per cell (A-C), cell volume (D-F) or as dry biomass percentage (G-I) of Coelastrella rubescens in the beginning (1) and in the end (2-4) of the "red" stage. 2, air-sparged control; 3, $\mathrm{CO}_{2}$-supplemented culture; 4, NaAc-supplemented culture; Car., carotenoids.

tures under the same conditions resulting in the loss of a large part of the cells accumulated at the "green" stage. In all variants studied, the cell density of the C. rubescens cultures increased by $30-50 \%$ by the end of the experiment.

The cessation of cell division was accompanied by the characteristic changes in cell size distribution constituted by the 2.5- to 4.0-fold increase in the average volume of autospores by the end of the "red" stage (Fig. 3B-E). These changes were most pronounced in the cultures supplemented with $\mathrm{CO}_{2}(\mathrm{pH} 5)$ where the proportion of large $(\mathrm{V}>$ 120 мкм $^{3}$ ) senescing cells increased from 2 to $65 \%$ whereas the control $(\mathrm{pH}$ 7.9-9.2) and the NaAc-supplemented cultures ( $\mathrm{pH}$ 7.9-8.9) features 1.5- to 2-time lower proportion of these cells (Fig. 3C-E).

At the same time, the cells of the $\mathrm{CO}_{2}$-supplemented and control cultures changed their cell shape from elliptic $(\mathrm{L} / \mathrm{D}=1.05-1.8)$ to spherical suggesting that the cells are nearing the resting state (Andreyeva 1998). In these cultures, the spherical cells amounted, at the eighth day, $42 \%$ and $33 \%$, respectively. The NaAc supplementation did not affect the cell form distribution in the cultures.

\section{Pigment content and composition of Coelastrel- la rubescens cells at different cultivation stages}

The most characteristic and spectacular stress responses in carotenogenic microalgae are constituted by the drastic change of their pigment profile (Boussiba 2000, Lemoine and Schoefs 2010, Shah et al. 2016). This type of a response was documented in the stressed C. rubescens cells (Fig. 4). Taking into account that a considerable increase of average cell volume by the end of the "red" stage took place in all experimental variants, but to a significantly different extent, we normalized pigment content to the cell volume. Content of $\mathrm{Chl} a$ and $b$ 


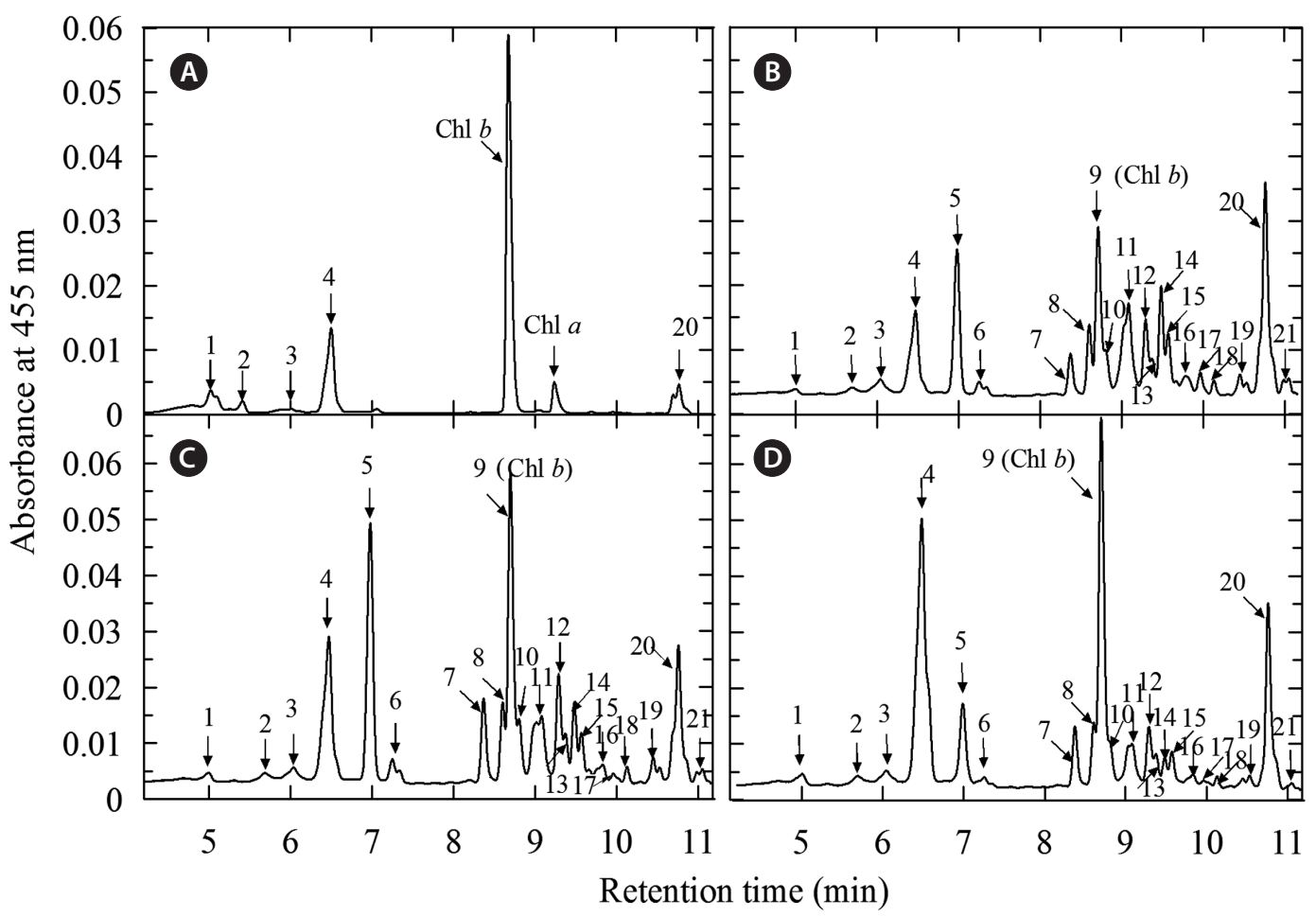

Fig. 5. Carotenoid composition of Coelastrella rubescens at the end of the "green" (A) and "red" stages after $7 \mathrm{~d}$ of air sparging (B-D) without or with supplementation (B) of $\mathrm{CO}_{2}$ (C) or NaAc (D). Peak designation: 1, neoxanthin; 2, violaxanthin; 3, anteraxanthin; 4, lutein + zeaxanthin; 5, 6, canthaxanthin; $7,10,12,13,16$, astaxanthin monoesters; $8,14,15,17$, adonixanthin monoesters; 11 , adonixanthin monoesters + echinenone; 18 , 19, 21, astaxanthin diesters; $20, a$ - and $\beta$-carotene. See also Table 1.

expressed per $\mu \mathrm{m}^{3}$ of cell volume declined during 8 days by 14-31 (Fig. 4D) and 12-26 times (Fig. 4E), respectively. Remarkably, the largest extent of Chl decline was found in the control culture limited by the three main nutrients $(\mathrm{N}, \mathrm{P}$, inorganic $\mathrm{C})$ whereas the highest retention of $\mathrm{Chl}$ was typical of the NaAc-supplemented culture. Noteworthy, the cell volume-based representation of the pigment content turned to be handy for the analysis of the data on the microalgal pigment composition. Thus, the cell density-based content of total Car attained by the end of the "red" stage (0.8-1.1 $\left.\mathrm{pg} \mathrm{cell}^{-1}\right)$ did not differ significantly from the initial value $\left(1.0 \mathrm{pg} \mathrm{cell}^{-1}\right)$ regardless of the stress treatment. By contrast, the cell-volume based Car content (Fig. 4C) and their DW percentages (Fig. 4I) declined 3.0 to 3.7 - and 2.1 to 6.1 -fold, respectively, by the end of the "red" stage.

Unexpectedly, the NaAc-supplemented cultures displayed the lowest total Car percentages of DW and a lack of Car accumulation $\left(-0.002 \mathrm{mg} \mathrm{L}^{-1} \mathrm{~d}^{-1}\right.$ vs. 0.25 or $0.18 \mathrm{mg}$ $\mathrm{L}^{-1} \mathrm{~d}^{-1}$ in the air-sparged control or the $\mathrm{CO}_{2}$-supplemented cultures, respectively).

The decline of Car productivity in the $\mathrm{CO}_{2}$-supple- mented cultures was not apparent since the latter took a bright orange color whereas the NaAc-supplemented cultures remained brown. This change of the culture color was a visual manifestation of the two opposite-directed processes: degradation of the photosynthetic pigments (chlorophylls and primary Car) and accumulation of secondary Car as evidenced by the characteristic changes of the C. rubescens cell extract absorbance spectra (not shown) and their Car profiles resolved by HPLC (Table 1, Fig. 5).

The data on the secondary Car in stressed Coelastrella cells appeared to be surprisingly scarce in the literature available to us; for a remarkable exception (Hu et al. 2013). Therefore, we paid special attention to the composition of these pigments in studied microalga. A considerable decline in photosynthetic pigment ( $\mathrm{Chl} a$ and $b$ as well as lutein) took place along with the build-up of cantaxanthin and monoesters of ketocarotenoids (Fig. 5). Qualitatively, the composition of the secondary Car accumulated during the stress exposure resembled that in a $H$. pluvalis strain IPPAS H-2018 isolated from White Sea (Chekanov et al. 2014) excepting the presence of notable amounts of 
canthaxanthin and adonixanthin monoesters.

The presence of a large $(30-60 \%$ of the total Car) amount of photosynthetic Car and astaxanthin precursors in the cells of the 8-day-old "red" stage culture suggested that formation of the secondary Car pool and hence the transition of the microalga to the resting stage was incomplete. Further optimization of stressing conditions (duration of the "red" stage, irradiance, chemical stimulation of secondary carotenogenesis) might turn to be necessary for acceleration of the aplanospore maturation and increase in the proportion of secondary ketocarotenoids in total Car. This finding can also indicate that C. rubescens belong to a peculiar group of chlorophytes (mainly edaphophylic and aerophylic) whose resting cells feature a complex composition of secondary Car dominated by astaxanthin together with its precursors (Liu and Lee 2000, Abe et al. 2007). Still, this species holds a promise for biotechnology due to its advantages such as high growth rate exceeding that of $H$. pluvialis and considerably higher environmental stress tolerance. According to our preliminary estimations, the upper limit of heat stress tolerance in the rapidly dividing "green" cells of $C$. rubescens is $33-35^{\circ} \mathrm{C}$ whereas the temperatures $40-42^{\circ} \mathrm{C}$ induce the transition to the "red" stage. Furthermore, this organism is suitable for outdoor cultivation in open systems since, at a sufficiently high cell density, its cultures are relatively resistant to algal contamination and protozoan grazing (not shown). Considering the 11-fold dilution of the culture during the transition to the "red" stage and the initial cell density of $1.1 \times 10^{6}$ cells $\mathrm{mL}^{-1}(0.17$ $\pm 0.01 \mathrm{~g} \mathrm{~L}^{-1} \mathrm{DW}$ ), the net Car productivity was $2.75 \pm 0.49$ or $2.03 \pm 0.19 \mathrm{mg} \mathrm{L}^{-1} \mathrm{~d}^{-1}$ in the air-sparged control or the
$\mathrm{CO}_{2}$-supplemented cultures, respectively suggesting the feasibility of commercial production of carotenoids with C. rubescens under the studied conditions.

\section{Proximate composition of the stressed Coelas- trella rubescens cells}

The nutrient-starving cells of $C$. rubescens vigorously accumulated DW (Fig. 6A-C): its content in the 11-fold diluted cultures increased 2.4- to 2.6-fold over 8 days of cultivation (Fig. 6A). This acclimatory response is common for all carotenogenic microalgae. Its magnitude depends on the nature and intensity of the stress as well as on the microalgal species (Boussiba 2000, Lemonie and Schoefs 2010, Juneja et al. 2013). In this case average DW productivity of $C$. rubescens did not differ in the air-sparged control and the $\mathrm{CO}_{2}$-supplemented cultures (77.8-77.9 $\left.\mathrm{mg} \mathrm{L}^{-1} \mathrm{~d}^{-1}\right)$ whereas it was considerably lower in the NaAcsupplemented cultures $\left(28.8 \mathrm{mg} \mathrm{L}^{-1} \mathrm{~d}^{-1}\right)$ in accord with a lower final cell density (Fig. 3A) and per cell DW content (Figs 3B \& 6B) of the "green" culture. At the same time, the NaAc-supplemented cultures possessed the highest DW content expressed per $\mu^{3}$ cell $\left(2.20 \pm 0.31 \mathrm{pg}_{\mu \mathrm{m}}{ }^{-3}\right.$ vs. $1.53 \pm 0.16$ or $0.85 \pm 0.20 \mathrm{pg} \mathrm{\mu m}^{-3}$ in the control or $\mathrm{CO}_{2}{ }^{-}$ supplemented cultures, respectively (Fig. 6C).

Enhanced accumulation of dry weight in the presence of NaAc is likely due to the ease of its assimilation by chlorophyte cells which readily take up and assimilate NaAc via several metabolic pathways accepting acetyl-CoA (Wiessner 1979, Nelson and Cox 2013). Another possibility under illuminated conditions is oxidation of $\mathrm{NaAc}$ to $\mathrm{CO}_{2}$ with subsequent assimilation of the latter in the bio-

Table 1. Carotenoid composition of Coelastrella rubescens stressed cells depending on cultivation mode (\% total)

\begin{tabular}{lcrrr}
\hline \multicolumn{1}{c}{ Carotenoid species } & \multirow{2}{*}{$\begin{array}{c}\text { Green stage of } \\
\text { cultivation }\end{array}$} & \multicolumn{3}{c}{ Red stage of cultivation } \\
\cline { 3 - 5 } & & \multicolumn{1}{c}{ Air } & \multicolumn{1}{c}{$\mathbf{C O}_{2}$} & $1.62 \pm 0.25$ \\
\hline Neoxanthin & 19.70 & $0.71 \pm 0.06$ & $1.21 \pm 0.28$ & $1.38 \pm 0.33$ \\
Violaxanthin & 6.45 & $1.24 \pm 0.25$ & $1.56 \pm 0.32$ & $2.62 \pm 0.26$ \\
Anteraxanthin & 4.50 & $2.54 \pm 0.33$ & $2.13 \pm 0.25$ & $37.89 \pm 0.15$ \\
Lutein + zeaxanthin & 45.30 & $11.48 \pm 0.78$ & $16.15 \pm 1.30$ & $8.63 \pm 0.39$ \\
Canthaxanthin & - & $12.73 \pm 0.56$ & $19.36 \pm 1.88$ & $15.28 \pm 0.64$ \\
Astaxanthin FA monoesters & - & $18.26 \pm 1.03$ & $19.86 \pm 1.00$ & $9.72 \pm 0.11$ \\
Adonixanthin FA monoesters & - & $17.98 \pm 0.83$ & $12.49 \pm 0.24$ & $3.35 \pm 0.44$ \\
Echinenone + adonixanthin FA monoesters & - & $10.84 \pm 0.05$ & $5.70 \pm 1.03$ & $4.34 \pm 0.16$ \\
Astaxanthin FA diesters & - & $7.95 \pm 0.85$ & $5.70 \pm 1.03$ & $12.09 \pm 0.72$ \\
-Arotene + $\alpha$-carotene & 20.89 & $13.67 \pm 1.29$ & $8.54 \pm 0.84$ & $0.87 \pm 0.36$ \\
Unidentified carotenoids & 3.16 & $2.59 \pm 0.60$ & $2.21 \pm 0.67$ & $58.05 \pm 0.53$ \\
Photosynthetic carotenoids & - & $32.24 \pm 2.39$ & $31.50 \pm 0.82$ & $41.95 \pm 0.53$ \\
Ketocarotenoids & - & $67.76 \pm 2.39$ & $68.50 \pm 0.82$ & \\
\hline
\end{tabular}

FA, fatty acids. 

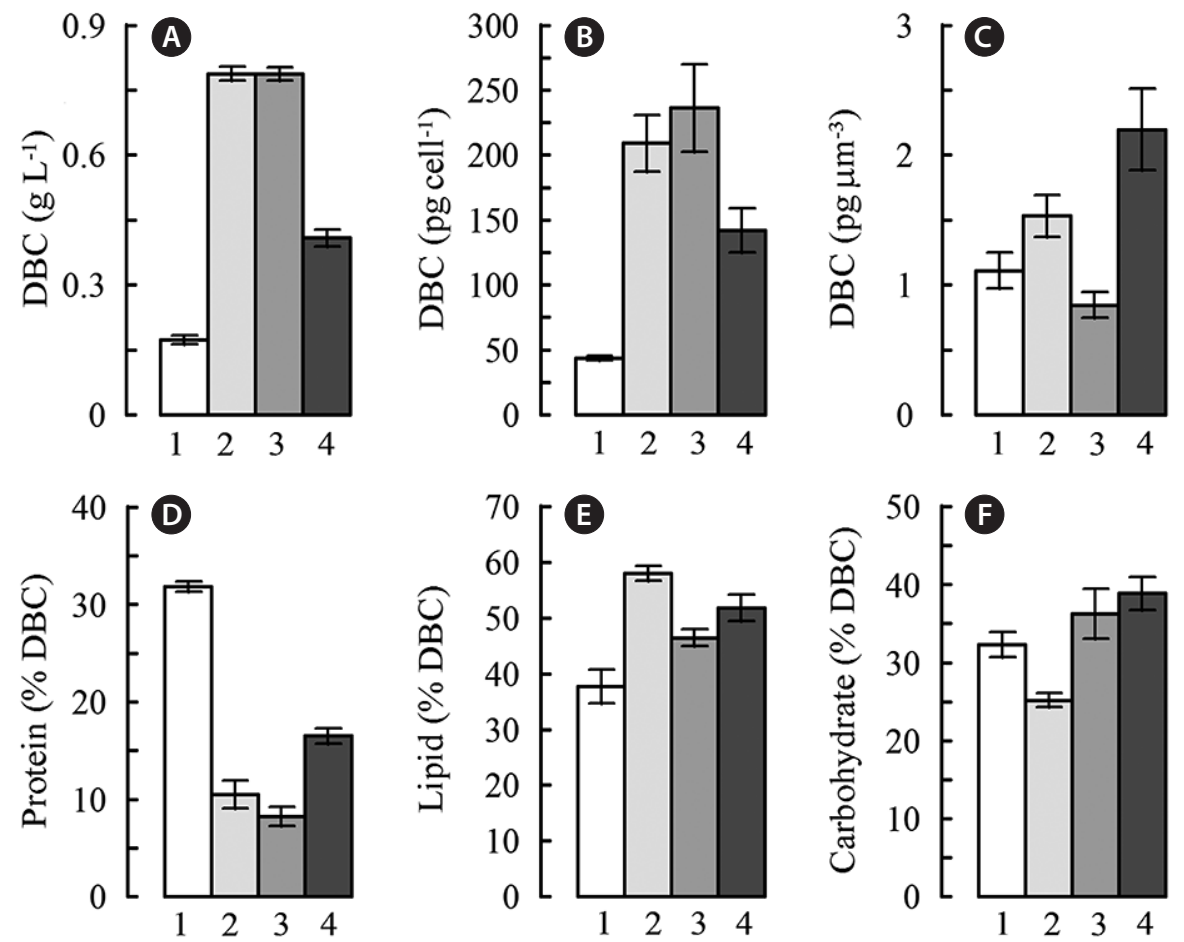

Fig. 6. Dry weight content per liter of culture (A), cell (B), or $\mu \mathrm{m}^{3}$ cell volume (C) and its protein (D), lipid (E), and content (F) of the "green" (1) and "red" (2-4) cells sparged with air (2), supplemented with $\mathrm{CO}_{2}$ (3) or $\mathrm{NaAc}$ (4). DBC, dry biomass content.

syntheses of carbohydrates and lipids (Singh et al. 2014).

We documented a sharp decline in protein percentage of DW (from 31.8 to $8.2-16.5 \%$ ) (Fig. 6D) typical of the stressed of carotenogenic microalgae cells (Boussiba 2000). Particularly, decline in the protein content of the cell might be related with nitrogen shortage and re-allocation of this essential nutrient by means of stress-induced autophagy (Pérez-Pérez et al. 2012, Nelson and Cox 2013). The maximum decline in the protein percentage of DW ( $74 \%$ of the initial level) was recorded in the $\mathrm{CO}_{2}$-supplemented cultures. At the same time, the stressed cultures displayed the slow-down of cell division and accumulation of carbon-rich reserves, mainly lipids. Lipid DW percentage comprised 1.2- to 1.5-fold in all stressed cells (Fig. 6E), whereas a significant carbohydrate content took place only in the cultures supplemented with $\mathrm{NaAc}$ (by $20.4 \%$ ) (Fig. 6F). The average lipid productivity in the airsparged and $\mathrm{CO}_{2}$-supplemented cultures was two times higher than in NaAc-supplemented cultures $(61.03 \pm 4.08$ and $67.37 \pm 5.60$ vs. $\left.31.31 \pm 1.97 \mathrm{mg} \mathrm{L}^{-1} \mathrm{~d}^{-1}\right)$. Taking into account the initial cell density of $1 \times 10^{6}$ cell $\mathrm{mL}^{-1}$ and 11 -fold dilution before the onset of the stress, the lipid productivity (and total lipid yield, $\mathrm{P}_{\mathrm{AVG}}$ over $19 \mathrm{~d}$ ) constituted 292.95 $\pm 19.67 \mathrm{mg} \mathrm{L}^{-1} \mathrm{~d}^{-1}(5.57 \mathrm{~g})$ in the air-sparged control and
$314.85 \pm 26.15 \mathrm{mg} \mathrm{L}^{-1} \mathrm{~d}^{-1}(5.98 \mathrm{~g})$ in the $\mathrm{CO}_{2}$-supplemented culture whereas in the NaAc-supplemented culture it was only $148.97 \pm 9.37 \mathrm{mg} \mathrm{L}^{-1} \mathrm{~d}^{-1}(2.83 \mathrm{~g})$.

\section{Changes in fatty acid profile and suitability to conversion into implication biodiesel}

The accumulation of lipids in C. rubescens occurred along with decline in their FA unsaturation which is typical of carotenogenic microalgale under stress (Lemoine and Schoefs 2010, Solovchenko 2013). The main driver of this processes was a dramatic (2.3- to 2.7-fold) decline in trienoic FA ( $\alpha$-linolenic acid, ALA, C18:3 $3^{\Delta 9,12,15}$ and hexadecatrienoic acid, $\left.\mathrm{C} 16: 3^{\triangle 4,7,10}\right)$ on the background of nearly 3-time increase in monounsaturated FA (mainly oleic acid, OA, C18:1 $1^{\perp 9}$ ) (Table 2). Net result of this was a 1.3-fold decline of the lipid FA Unsaturation Index (UI) and a dramatic (11- to 15-fold) buildup of the OA / ALA ratio which is perfectly in line with the FA profile changes observed in other chlorophytes including carotenogenic species (Solovchenko 2013).

Acidification of the medium to the $\mathrm{pH} 5$ by $\mathrm{CO}_{2}$ injection significantly affected Car DW percentage (Fig. 4) but exerted a little effect on the FA profile except a weak 
(5.5\%) decline in monounsaturated and saturated FA. At the same time, a notable (26.5\%) increase in trienoic FA (ALA and C16:344,7,10 and C18:3 $3^{\Delta, 12,15}$ ) was documented in this experimental variant (Table 2).

A potentially beneficial trait of the increase in the $C$. rubescens cell lipid FA saturation at the "red" stage is increase of its suitability for the conversion into biosiesel. To estimate the suitability of the cell lipid FA of the micro-

Table 2. Fatty acid (FA) composition of total cell lipids of Coelastrella rubescens in the beginning and in the end of the "red" stage cultivation

\begin{tabular}{|c|c|c|c|}
\hline \multirow{3}{*}{ Fatty acid ${ }^{\mathrm{b}}$} & \multicolumn{3}{|c|}{ Fatty acid content (mass \%) ${ }^{\mathrm{a}}$} \\
\hline & \multirow{2}{*}{$\begin{array}{l}\text { Beginning of } \\
\text { the "red" stage }\end{array}$} & \multicolumn{2}{|c|}{ End of the "red" stage } \\
\hline & & Air & $\mathrm{CO}_{2}$ \\
\hline C16:0 & 20.5 & 14.4 & 14.7 \\
\hline $\mathrm{C} 16: 1^{\Delta 7}$ & 1.0 & 2.1 & 1.1 \\
\hline $\mathrm{C} 16: 1^{\Delta 9}$ & 2.2 & 0.2 & 0.2 \\
\hline $\mathrm{C} 16: 2^{\Delta 7,10}$ & 5.5 & 8.8 & 6.2 \\
\hline $\mathrm{C} 16: 3^{\Delta 4,7,10}$ & 8.5 & 3.4 & 5.2 \\
\hline C18:0 & 0.8 & 3.2 & 1.7 \\
\hline $\mathrm{C} 18: 1^{\Delta 9}(\mathrm{OA})$ & 6.8 & 32.7 & 31.0 \\
\hline $\mathrm{C} 18: 1^{\Delta 11}$ & 1.4 & 0.8 & 0.8 \\
\hline $\mathrm{C} 18: 2^{\Delta 9,12}$ & 20.8 & 21.5 & 23.0 \\
\hline $\mathrm{C} 18: 3^{\Delta 9,12,15}$ (ALA) & 30.4 & 10.2 & 12.0 \\
\hline Saturated & 22.0 & 19.9 & 18.9 \\
\hline Monoenoic & 11.6 & 36.4 & 34.3 \\
\hline Dienoic & 26.3 & 30.3 & 29.2 \\
\hline Trienoic & 38.9 & 13.6 & 17.2 \\
\hline $\begin{array}{l}\text { Medium chain } \\
\text { length FA }(C<16)\end{array}$ & 0.5 & 0.3 & 0.4 \\
\hline $\begin{array}{l}\text { Very long chain FA } \\
(C \geq 20)\end{array}$ & 0.4 & 2.5 & 3.4 \\
\hline ALA / OA & 4.5 & 0.3 & 0.4 \\
\hline Unsaturation index & 1.851 & 1.379 & 1.443 \\
\hline
\end{tabular}

${ }^{a}$ The standard deviation was in all cases below $5 \%$ of the corresponding average.

${ }^{\mathrm{b}}$ Minor FA were also detected (not shown) including C16:1 $\omega 9, \mathrm{C} 16: 4$ $\omega 3$, and C16:3 $\omega 6$ ( $\leq 1 \%$ each). alga we used the empirical equations (Islam et al. 2013, Karpagam et al. 2015) relating the FA profile of the biomass and properties of the biodiesel generated from it. Biodiesel fuel specifications as given by the international standard EN14214 in Europe (Hoekman et al. 2012). Generally, cetane number, iodine number, saponification number, degree of unsaturation, long chain saturation factor, and cold filter plugging point were calculated from the FA profile (Table 3). The biomass obtained at the "green" stage enriched in lipids harboring two essential FA (linoleic acid and ALA, totaling to $50 \%$ of total FA) can be utilized for the production e.g., of food and feed additives. By contrast, the biomass obtained at the "red" stage is highly suitable for obtaining of high quality biodiesel according to the European standard EN14214, the strictest international standard for biodiesel.

\section{CONCLUSION}

We studied stress-induced changes, including the secondary carotenogenesis, in a biotechnologically promising strain IPPAS H-350 of the chlorophyte C. rubescens Vinatzer/Innsbruck V 195 which largely escaped the attention of researchers so far. The data on the biomass accumulation and its biochemical composition obtained for the stressed cultures suggest that it is a potentially double-purpose organism. On one hand, C. rubescens can represent a source of secondary Car mixture with a considerable proportion of a value-added ketocarotenoids astaxanthin and canthaxanthin. The biomass of the microalga enriched in Car can be converted to feed additive. On the other hand, the total cell lipids of the microalga can be converted to a high-quality EN14214 standardcomplying biodiesel. Unlike other carotenogenic microalgae, C. rubescens did not respond by increase in the Car productivity of the cultures to supplementation with

Table 3. Quality parameters of the biodiesel from Coelastrella rubescens cell lipids calculated via its fatty acid profile according to Karpagam et al. (2015)

\begin{tabular}{lcccc}
\hline \multirow{2}{*}{ Parameter } & End of the & \multicolumn{2}{c}{ End of the "red" stage } & \multicolumn{2}{c}{ European standard } \\
\cline { 3 - 3 } & "green" stage & Air-sparged & CO $_{2}$-supplemented & EN14214 \\
\hline Saponification number $(\mathrm{mg} \mathrm{KOH} / \mathrm{g}$ oil) & $197.71 \pm 0.10$ & $194.80 \pm 0.27$ & $193.82 \pm 0.18$ & $187-191$ \\
Iodine number $\left(\mathrm{g} \mathrm{I}_{2} / 100 \mathrm{~g}\right.$ oil) & $164.30 \pm 1.63$ & $81.10 \pm 1.49$ & $78.85 \pm 2.37$ & $<120$ \\
Cetane number & $36.94 \pm 0.38$ & $56.07 \pm 0.37$ & $56.72 \pm 0.56$ & $>51$ \\
Oxidation resistance, $100^{\circ} \mathrm{C}(\mathrm{h})$ & $4.90 \pm 0.02$ & $13.15 \pm 0.2$ & $12.05 \pm 0.21$ & $>6$ \\
Long chain saturation factor & $2.75 \pm 0.13$ & $5.05 \pm 0.09$ & $5.01 \pm 0.39$ & Depends on climatic zone \\
Cold filter plugging point $\left({ }^{\circ} \mathrm{C}\right)$ & $-7.8 \pm 0.40$ & $-0.75 \pm 0.07$ & $-1.55 \pm 0.59$ & $\leq 5 / \leq-20$ \\
18:3 methyl esters (mass $\%)$ & 30.4 & 10.2 & 12.0 & $\leq 12$ \\
\hline
\end{tabular}


either inorganic $\left(\mathrm{CO}_{2}\right)$ or organic (NaAc) carbon on the background of the low-pH stress. C. rubescens features a complex composition of secondary Car dominated by astaxanthin together with its precursors. Still, this species holds a promise for biotechnology due to its advantages such as high growth rate exceeding that of $H$. pluvialis and considerably higher environmental stress tolerance.

\section{ACKNOWLEDGEMENTS}

The carotenoid analysis in this work was supported by Russian Science Foundation (grant 14-50-00029). Dedicated help of Dr. Olga Chivkunova and Dr. Roman Sidorov with fatty acid analysis is gratefully appreciated.

\section{SUPPLEMENTARY MATERIAL}

Supplementary Fig. S1. Light (A \& B) and scanning electron micrographs $(C \& D)$ of the green $(A \& C)$ and red (B) cells of Coelastrella rubescens studied in the present work (http://www.e-algae.org).

\section{REFERENCES}

Abe, K., Hattori, H. \& Hirano, M. 2007. Accumulation and antioxidant activity of secondary carotenoids in the aerial microalga Coelastrella striolata var. multistriata. Food Chem. 100:656-661.

Ahlgren, G. \& Merino, L. 1991. Lipid analysis of freshwater microalgae: a method study. Arch. Hydrobiol. 121:295306.

Altschul, S. F., Gish, W., Miller, W., Myers, E. W. \& Lipman, D. J. 1990. Basic local alignment search tool. J. Mol. Biol. 215:403-410.

Andreyeva, V. 1998. Terrestrial and aerophilic green algae (Chlorophyta: Terasporales, Chlorococcales, Chlorosarcinales). Nauka, St. Petersburg, 349 pp.

Beers, R. F. Jr. \& Sizer, I. W. 1956. Progressive inhibition of the catalase-hydrogen peroxide system by acetate, chloride and azide. Arch. Biochem. Biophys. 60:115-125.

Bishoff, H. \& Bold, H. C. 1963. Phycological studies. IV. Some soil algae from enchanted rock and related algae species. University of Texas Publication, Austin, TX, 95 pp.

Bligh, E. G. \& Dyer, W. J. 1959. A rapid method of total lipid extraction and purification. Can. J. Biochem. Physiol. 37:911-917.

Borowitzka, M. 2013. Dunaliella: biology, production, and markets. In Richmond, A. \& Hu, Q. (Eds.) Handbook of Microalgal Culture: Applied Phycology and Biotechnology. 2nd ed. Wiley-Blackwell, West Sussex, pp. 359-368.

Borowitzka, M. A. \& Moheimani, N. R. 2013. Sustainable biofuels from algae. Mitig. Adapt. Strateg. Glob. Change 18:13-25.

Bouarab, L., Dauta, A. \& Loudiki, M. 2004. Heterotrophic and mixotrophic growth of Micractinium pusillum Fresenius in the presence of acetate and glucose: effect of light and acetate gradient concentration. Water Res. 38:27062712.

Boussiba, S. 2000. Carotenogenesis in the green alga Haematococcus pluvialis: cellular physiology and stress response. Physiol. Plant. 108:111-117.

Brown, T. E., Richardson, F. L. \& Vaughn, M. L. 1967. Development of red pigmentation in Chlorococcum wimmeri (Chlorophyta: Chlorococcales). Phycologia 6:167-184.

Buchheim, M. A., Sutherland, D. M., Buchheim, J. A. \& Wolf, M. 2013. The blood alga: phylogeny of Haematococcus (Chlorophyceae) inferred from ribosomal RNA gene sequence data. Eur. J. Phycol. 48:318-329.

Chekanov, K., Lobakova, E., Selyakh, I., Semenova, L., Sidorov, R. \& Solovchenko, A. 2014. Accumulation of astaxanthin by a new Haematococcus pluvialis strain BM1 from the White Sea coastal rocks (Russia). Mar. Drugs 12:45044520 .

Chelebieva, E. S., Minyuk, G. S., Drobetskaya, I. V. \& Chubchikova, I. N. 2013. Physiological and biochemical characteristics of Ettlia carotinosa Komárek 1989 (Chlorophyceae) under experimental stress condition. Mors'kyi Ekolohichnyi Zhurnal 12:78-87.

Chubchikova, I. N., Minyuk, G. S. \& Drobetskaya, I. V. 2010. Secondary carotenogenesis in green microalgae Scotiellopsis rubescens Vinatz. under natural insolation and temperature. Ekologiya Morya 81:77-81.

Chubchikova, I. N., Minyuk, G. S., Drobetskaya, I. V. \& Dantsyuk, N. V. 2009. Chlorococcal microalgae as source of natural secondary carotenoids. Ekologiya Morya 77:7783.

DuBois, M., Gilles, K. A., Hamilton, J. K., Rebers, P. A. \& Smith, F. 1956. Colorimetric method for determination of sugars and related substances. Anal. Chem. 28:350-356.

Edgar, R. C. 2004. MUSCLE: multiple sequence alignment with high accuracy and high throughput. Nucleic Acids Res. 32:1792-1797.

Fábregas, J., Otero, A., Maseda, A. \& Domínguez, A. 2001. Two-stage cultures for the production of astaxanthin from Haematococcus pluvialis. J. Biotechnol. 89:65-71.

Felsenstein, J. 1985. Confidence limits on phylogenies: an approach using the bootstrap. Evolution 39:783-791. 
Han, D., Li, Y. \& Hu, Q. 2013. Biology and commercial aspects of Haematococcus pluvialis. In Richmond, A. \& Hu, Q. (Eds.) Handbook of Microalgal Culture: Applied Phycology and Biotechnology. 2nd ed. Wiley-Blackwell, West Sussex, pp. 388-405.

Hanagata, N. 1998. Phylogeny of the subfamily Scotiellocystoideae (Chlorophyceae, Chlorophyta) and related taxa inferred from $18 \mathrm{~S}$ ribosomal RNA gene sequence data. J. Phycol. 34:1049-1054.

Heifetz, P. B., Förster, B., Osmond, C. B., Giles, L. J. \& Boynton, J. E. 2000. Effects of acetate on facultative autotrophy in Chlamydomonas reinhardtii assessed by photosynthetic measurements and stable isotope analyses. Plant Physiol. 122:1439-1445.

Hoekman, S. K., Broch, A., Robbins, C., Ceniceros, E. \& Natarajan, M. 2012. Review of biodiesel composition, properties, and specifications. Renew. Sustain. Energy Rev. 16:143-169.

Hu, C. -W., Chuang, L. -T., Yu, P. -C. \& Chen, C. -N. N. 2013. Pigment production by a new thermotolerant microalga Coelastrella sp. F50. Food Chem. 138:2071-2078.

Hyka, P., Lickova, S., Přibyl, P., Melzoch, K. \& Kovar, K. 2013. Flow cytometry for the development of biotechnological processes with microalgae. Biotechnol. Adv. 31:2-16.

Islam, M. A., Magnusson, M., Brown, R. J., Ayoko, G. A., Nabi, M. N. \& Heimann, K. 2013. Microalgal species selection for biodiesel production based on fuel properties derived from fatty acid profiles. Energies 6:5676-5702.

Ji, F., Liu, Y., Li, G., Zhou, Y., Tian, L., Ma, Z. \& Dong, R. 2013. Effects of glucose, acetic acid and glycerol on biomass accumulation of Chlorella sp. In Proc. Am. Soc. Agr. Biol. Eng. Kansas City, Missouri, 2013 July 21-24. American Society of Agricultural and Biological Engineers, St. Joseph, MI, No. 131620778.

Juneja, A., Ceballos, R. M. \& Murthy, G. S. 2013. Effects of environmental factors and nutrient availability on the biochemical composition of algae for biofuels production: a review. Energies 6:4607-4638.

Karpagam, R., Raj, K. J., Ashokkumar, B. \& Varalakshmi, P. 2015. Characterization and fatty acid profiling in two fresh water microalgae for biodiesel production: lipid enhancement methods and media optimization using response surface methodology. Bioresour. Technol. 188:177-184.

Kaufnerová, V. \& Eliáš, M. 2013. The demise of the genus Scotiellopsis Vinatzer (Chlorophyta). Nova Hedwigia 97:415-428.

Kobayashi, M., Kakizono, T. \& Nagai, S. 1993. Enhanced carotenoid biosynthesis by oxidative stress in acetate-induced cyst cells of a green unicellular alga, Haematococ- cus pluvialis. Appl. Environ. Microbiol. 59:867-873.

Kessler, E. \& Czygan, F. 1965. Chlorella zofingiensis Donz: Isolierung neuer Stamme und ihre physiologisch-biochemischen Eigenschaften. Ber. Deutsch. Bot. Gesell. 78:342-347.

Lam, M. K. \& Lee, K. T. 2011. Microalgae biofuels: a critical review of issues, problems and the way forward. Biotechnol. Adv. 30:673-690.

Lemoine, Y. \& Schoefs, B. 2010. Secondary ketocarotenoid astaxanthin biosynthesis in algae: a multifunctional response to stress. Photosynth. Res. 106:155-177.

Leu, S. \& Boussiba, S. 2014. Advances in the production of high-value products by microalgae. Ind. Biotechnol. 10:169-183.

Lichtenthaler, H. K. 1987. Chlorophyll and carotenoids: pigments of photosynthetic biomembranes. Methods Enzymol. 148:350-382.

Liu, B. -H. \& Lee, Y. -K. 2000. Secondary carotenoids formation by the green alga Chlorococcum sp. J. Appl. Phycol. 12:301-307.

Liu, F. J., Li, S. X., Huang, B. Q., Zheng, F. Y. \& Huang, X. G. 2016. Effect of excessive $\mathrm{CO}_{2}$ on physiological functions in coastal diatom. Sci. Rep. 6:21694.

Lorenz, R. T. \& Cysewski, G. R. 2000. Commercial potential for Haematococcus microalgae as a natural source of astaxanthin. Trends Biotechnol. 18:160-167.

Lowry, O. H., Rosebrough, N. J., Farr, A. L. \& Randall, R. J. 1951. Protein measurement with the Folin phenol reagent. J. Biol. Chem. 193:265-275.

Minyuk, G. 2008. Physiological, biochemical, and biophysical characteristics of the microalga Haematococcus pluvialis, a promising source of natural astaxanthin. In Tokarev, Y. N., Finenko, Z. Z. \& Shadrin, N. V. (Eds.) The Black Sea Microalgae: Problems of Biodiversity Preservation and Biotechnological Usage. ECOSI-Gidrofizika, Sevastopol, pp. 353-392.

Minyuk, G. S., Chelebieva, E. S., Chubchikova, I. N., Dantsyuk, N. V., Drobetskaya, I. V., Sakhon, E. G., Chivkunova, O. B., Chekanov, K. A., Lobakova, E. S., Sidorov, R. A. \& Solovchenko, A. E. 2016. $\mathrm{pH}$ and $\mathrm{CO}_{2}$ effects on Coelastrella (Scotiellopsis) rubescens growth and metabolism. Russ. J. Plant Physiol. 63:566-574.

Minyuk, G. S., Drobetskaya, I. V., Chubchikova, I. N., Dantsyuk, N. V. \& Chelebieva, E. S. 2010. Screening of green microalgae as potential source of nature ketocarotenoids: the relevance, strategy and study approach. Ekologiya Morya 80:67-78.

Murphy, J. \& Riley, J. P. 1962. A modified single solution method for the determination of phosphate in natural waters. Anal. Chim. Acta 27:31-36. 
Nelson, D. L. \& Cox, M. M. 2013. Lehninger principles of biochemistry. 6th ed. MacMillan, New York, 1340 pp.

Özben, T. 2013. Free radicals, oxidative stress, and antioxidants: pathological and physiological significance. Vol. 296. Springer, New York, 395 pp.

Pal, D., Khozin-Goldberg, I., Cohen, Z. \& Boussiba, S. 2011. The effect of light, salinity, and nitrogen availability on lipid production by Nannochloropsis sp. Appl. Microbiol. Biotechnol. 90:1429-1441.

Pérez-Pérez, M. E., Lemaire, S. D. \& Crespo, J. L. 2012. Reactive oxygen species and autophagy in plants and algae. Plant Physiol. 160:156-164.

Punčochářová, M. \& Kalina, T. 1981. Taxonomy of the genus Scotiellopsis Vinatzer (Chlorococcales, Chlorophyta). Algol. Stud. 27:119-147.

Recht, L., Töpfer, N., Batushansky, A., Sikron, N., Gibon, Y., Fait, A., Nikoloski, Z., Boussiba, S. \& Zarka, A. 2014. Metabolite profiling and integrative modeling reveal metabolic constraints for carbon partitioning under nitrogen-starvation in the green alga Haematococcus pluvialis. J. Biol. Chem. 289:30387-30403.

Saitou, N. \& Nei, M. 1987. The neighbor-joining method: a new method for reconstructing phylogenetic trees. Mol Biol Evol 4:406-425.

Sarada, R., Bhattacharya, S., Bhattacharya, S. \& Ravishankar, G. A. 2002. A response surface approach for the production of natural pigment astaxanthin from green alga, Haematococcus pluvialis: effect of sodium acetate, culture age, and sodium chloride. Food Biotechnol. 16:107120.

Shah, M. M. R., Liang, Y., Cheng, J. J. \& Daroch, M. 2016. Astaxanthin-producing green microalga Haematococcus pluvialis: from single cell to high value commercial products. Front. Plant Sci. 7:531.

Singh, H., Shukla, M. R., Chary, K. V. R. \& Rao, B. J. 2014. Acetate and bicarbonate assimilation and metabolite formation in Chlamydomonas reinhardtii: a ${ }^{13} \mathrm{C}-\mathrm{NMR}$ study. PLoS ONE 9:e106457.

Solovchenko, A. E. 2013. Physiology and adaptive significance of secondary carotenogenesis in green microalgae. Russ. J. Plant Physiol. 60:1-13.

Solovchenko, A. E. 2015. Recent breakthroughs in the biology of astaxanthin accumulation by microalgal cell. Photosynth. Res. 125:437-449.

Solovchenko, A. \& Chekanov, K. 2014. Production of carot- enoids using microalgae cultivated in ohotobioreactors. In Paek, K. -Y., Murthy, H. N. \& Zhong, J. -J. (Eds.) Production of Biomass and Bioactive Compounds Using Bioreactor Technology. Springer, Dordrecht, pp. 63-91.

Solovchenko, A. \& Khozin-Goldberg, I. 2013. High- $\mathrm{CO}_{2}$ tolerance in microalgae: possible mechanisms and implications for biotechnology and bioremediation. Biotechnol. Lett. 35:1745-1752.

Solovchenko, A., Merzlyak, M. N., Khozin-Goldberg, I., Cohen, Z. \& Boussiba, S. 2010. Coordinated carotenoid and lipid syntheses induced in Parietochloris incisa (Chlorophyta, Trebouxiophyceae) mutant deficient in $\Delta 5$ desaturase by nitrogen starvation and high light. J. Phycol. 46:763-772.

Subramanian, S., Barry, A. N., Pieris, S. \& Sayre, R. T. 2013. Comparative energetics and kinetics of autotrophic lipid and starch metabolism in chlorophytic microalgae: implications for biomass and biofuel production. Biotechnol. Biofuels 6:150.

Tamura, K., Stecher, G., Peterson, D., Filipski, A. \& Kumar, S. 2013. MEGA6: molecular evolutionary genetics analysis version 6.0. Mol. Biol. Evol. 30:2725-2729.

Vonshak, A. 1985. Microalgae: laboratory growth techniques and outdoor biomass production. In Coombs, J., Hall, D. O., Long, S. P. \& Scurlock, J. M. O. (Eds.) Techniques in Bioproductivity and Photosynthesis. Pergamon Press, Oxford, pp. 188-203.

Wang, B., Zhang, Z., Hu, Q., Sommerfeld, M., Lu, Y. \& Han, D. 2014. Cellular capacities for high-light acclimation and changing lipid profiles across life cycle stages of the green alga Haematococcus pluvialis. PLoS ONE 9:e106679.

Wiessner, W. 1979. Photoassimilation of organic compounds. In Gibbs, M. \& Latzko, E. (Eds.) Encyclopedia of Plant Physiology. Springer Verlag, Berlin, pp. 181-189.

Wood, A. M., Everroad, R. C. \& Wingard, L. M. 2005. Measuring growth rates in microalgal cultures. In Anderson, R. A. (Ed.) Algal Culturing Techniques. Vol. 18. Elsevier Academic Press, Burlington, MA, pp. 269-288.

Yu, X., Chen, L. \& Zhang, W. 2015. Chemicals to enhance microalgal growth and accumulation of high-value bioproducts. Front. Microbiol. 6:56.

Zhang, D. H., Ng, Y. K. \& Phang, S. M. 1997. Composition and accumulation of secondary carotenoids in Chlorococcum sp. J. Appl. Phycol. 9:147-155. 